\title{
First record of Stenocader mapu Carpintero \& Montemayor, 2008 (Heteroptera: Tingidae) from Chile
}

\author{
Primer registro de Stenocader mapu \\ Carpintero \& Montemayor, 2008 (Heteroptera: Tingidae) en Chile
}

Eduardo I. Faúndez ${ }^{1,2} \&$ Alfredo Lüer ${ }^{3}$

Tingidae is a family of tiny phytophagous Heteropterans, commonly named lacebugs (Schuh \& Slater, 1995). Tingids live on plants, mainly under the leaves, on the roots, and in the canopy of trees, as well as at ground level on mosses, for example (Guilbert et al. 2014). There are about 2500 species of Tingids worldwide (Guilbert et al. 2014). In Chile we have actually 6 species of Tingidae (Faúndez \& Carvajal, 2014). Most of the Chilean tingids are classifided in the Tinginae, and just one Stenocader tingidoides (Spinola, 1852) (endemic of the country) is classified in the subfamily Cantacaderinae (Carpintero \& Montemayor, 2008).

Stenocader mapu Carpintero \& Montemayor, 2008 (Fig. 1) is a tingid described from the Argentinean Patagonia (Neuquén Province); no additional data have been published after its original description. The purpose of the present contribution is to give the first record of this species for Chile:

Material examined: Chile, Futaleufú, sector Piedra del Águila, 4309'28'S-71 53'28' 'W, 26-I-2015, A. Lüer leg. \& coll., 730 m s.n.m, 2 우우.

According to Carpintero \& Montemayor (2008), Stenocader mapu can be easily distinguished from its only congener $S$. tingidoides because of the following characters: S. mapu has just one spine on the anterior lobe of the pronotum and none on the posterior; whereas $S$. tingidoides has three spines on the anterior lobe and one on the tip of the posterior pronotal lobe. Additionally S. mapu has the pronotal lobes separated by a slight invagination; whereas $S$. tingidoides pronotal lobes are separated by a deep invagination. These characteristics match well with our specimens, which are becoming also the southernmost record for a Cantacaderinae species in Chile.

Stenocader mapu, was described from Argentinean localities very close to the boundary with Chile; therefore its presence in the country is not rare. The Chilean locality here given is also close to the Argentinean boundary (Fig. 2). Thus we believe that this species is distributed towards the Andes Mountains in the South of Chile and Argentina.

The finding of $S$. mapu in Chile was in a vegetation subregion known as Patagonian ridges (sensu Gajardo, 1994). This zone (Fig. 3.) is characterized by an arboreal layer, generally nonspecific, sparse understory, and few herbaceous elements. That landscape has been importantly altered by big past fires. The natural absence of Araucaria araucana (Molina) $\mathrm{K}$. Koch, the only known host plant of S. mapu, suggests that this Tingid species may not have very specific feeding habits.

1 Entomology Department, North Dakota State University, Dept. 7650, P.O. Box 6050; Fargo, ND ed.faundez@ gmail.com $\gg$

2 Departamento de Zoología Médica, Centro de Estudios en Biodiversidad (CEBCh), Magallanes, 1979, Osorno, Chile.

3 Panguilemo 261, Quilicura, Santiago, Chile, alfredoluer@ hotmail.com 


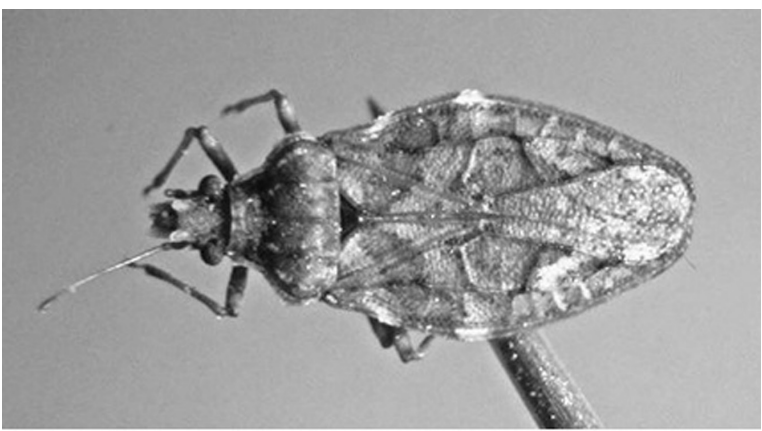

Fig. 1. Stenocader mapu Carpintero \& Montemayor 2008, female from Chile, habitus.

\section{LITERATURE CITED}

Carpintero, D. L. \& Montemayor, S. I. (2008). Revision of the Cantacaderinae (Heteroptera, Tingidae) from Argentina and Chile, with the description of a new species of Cantacaderini. Dtsch. Entomol. Z., 55(1), 109-116.

Faúndez, E. I. \& Carvajal, M. A. (2014). A new hostplant record for Coleopterodes liliputianum (Signoret, 1864) (Hemiptera: Heteroptera: Tingidae), with comments on its distribution in Chile. Boletin de Biodiversidad de Chile, 9, 42-45.

Gajardo, R. (1994). La vegetación natural de Chile. Clasificación y distribuciones geográficas. Editorial Universitaria, Santiago, Chile.

Guilbert, E., Damgaard, J. \& D'Haese, C. A. (2014). Phylogeny of the lacebugs (Insecta: Heteroptera:Tingidae) using morphological and molecular data. Systematic Entomology,

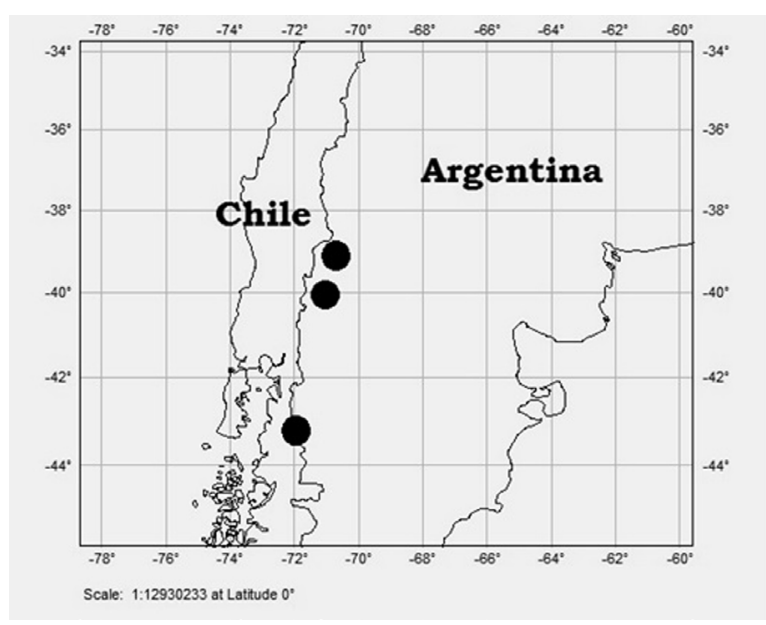

Fig. 2. Distribution of Stenocader mapu Carpintero \& Montemayor 2008.

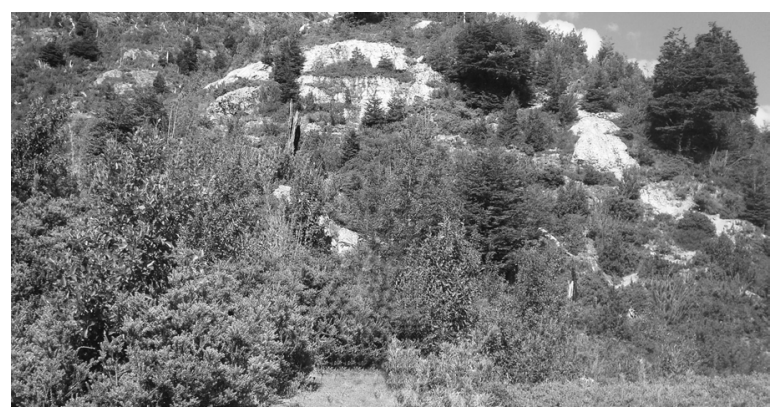

Fig. 3. Habitat of Stenocader mapu Carpintero \& Montemayor (2008), Piedra del Águila, Futaleufú, Chile.

39(3), 431-441.

Schuh, R. T. \& Slater, J. A. (1995). True bugs of the World (Hemiptera: Heteroptera). Classification and natural history. Cornell University Press, New York. 